\title{
Disc-shaped fossils resembling porpitids or eldonids from the early Cambrian (Series 2: Stage 4) of western U.S.A.
}

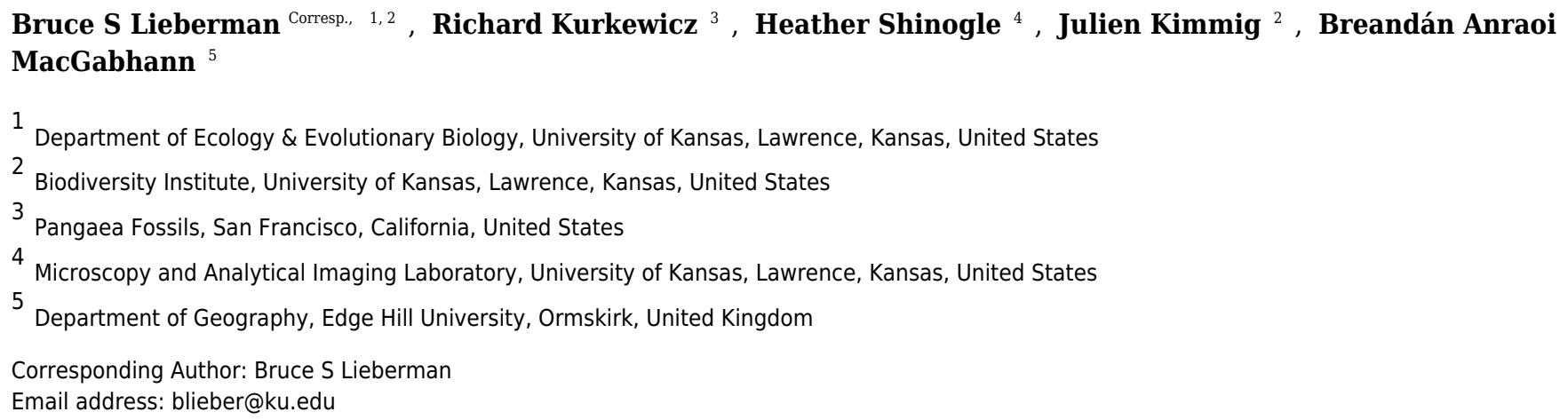

The morphology and affinities of newly discovered disc-shaped soft-bodied fossils from the early Cambrian (Series 2: Stage 4, Dyeran) Carrara Formation are discussed. These specimens show some similarity to the Ordovician Discophyllum Hall, 1847; traditionally this taxon had been treated as a fossil porpitid. However, recently it has instead been referred to another clade, the eldonids, which includes the enigmatic Eldonia Walcott, 1911 that was originally described from the Cambrian Burgess Shale. The status of various Proterozoic and Phanerozoic taxa previously referred to porpitids and eldonids is also briefly considered. To help ascertain that the specimens were not dubio- or pseudofossils, elemental mapping using energy dispersive X-ray spectroscopy (EDS) was conducted. This, in conjunction with the morphology of the specimens, indicated that the fossils were not hematite, iron sulfide, pyrolusite, or other abiologic mineral precipitates. Instead, their status as biologic structures and thus actual fossils is supported. Enrichment in the element carbon, and also possibly to some extent the elements magnesium and iron, seems to be playing some role in the preservation process. 


\section{Disc-shaped fossils resembling porpitids or eldonids from the early}

\section{Cambrian (Series 2: Stage 4) of western U.S.A.}

4 Bruce S. Lieberman ${ }^{1,2}$, Richard Kurkewicz ${ }^{4}$, Heather E. Shinogle ${ }^{3}$, Julien Kimmig ${ }^{2}$, Breandán 5 Anraoi MacGabhann ${ }^{5}$

$7 \quad{ }^{1}$ Department of Ecology \& Evolutionary Biology, ${ }^{2}$ Biodiversity Institute, and ${ }^{3}$ Microscopy and

8 Analytical Imaging Laboratory, University of Kansas, Lawrence, Kansas 66045, USA

9 4Pangaea Fossils, 584 Castro St., Apt. 501, San Francisco, California 94114, USA

$10{ }^{5}$ Geology, Department of Geography, Edge Hill University, St. Helens Road, Ormskirk, L39

$114 \mathrm{QP}$, England

14 Corresponding Author:

15 Bruce S. Lieberman ${ }^{1}$

17 Email address: blieber@ku.edu 
25 The morphology and affinities of newly discovered disc-shaped soft-bodied fossils from the 26 early Cambrian (Series 2: Stage 4, Dyeran) Carrara Formation are discussed. These specimens

27 show some similarity to the Ordovician Discophyllum peltatum Hall, 1847; traditionally this

28 taxon had been treated as a fossil porpitid. However, recently it has instead been referred to

29 another clade, the eldonids, which includes the enigmatic Eldonia Walcott, 1911 that was

30 originally described from the Cambrian Burgess Shale. The status of various Proterozoic and

31 Phanerozoic taxa previously referred to porpitids and eldonids is also briefly considered. To

32 help ascertain that the specimens were not dubio- or pseudofossils, elemental mapping using

33 energy dispersive X-ray spectroscopy (EDS) was conducted. This, in conjunction with the

34 morphology of the specimens, indicated that the fossils were not hematite, iron sulfide,

35 pyrolusite, or other abiologic mineral precipitates. Instead, their status as biologic structures and

36 thus actual fossils is supported. Enrichment in the element carbon, and also possibly to some

37 extent the elements magnesium and iron, seems to be playing some role in the preservation 38 process.

\section{Introduction}


Aspects of the Phanerozoic fossil record of disc-shaped fossils in general, and jellyfish

49 (medusozoans) fossils in particular, are somewhat cryptic, as the amount of character

50 information generally preserved with such soft-bodied cnidarian specimens tends to be limited

51 (though see Ossian, 1973, Cartwright et al., 2007 and Liu et al., 2014 for exceptions); thus, any

52 conclusions must be made with some caution (Hagadorn, Fedo, \& Waggoner, 2000). This is

53 especially apposite given Caster's (1942, p. 61) cautionary remark that "long scrutiny of

54 problematical objects has been known to engender hallucination." The degree of inscrutability

55 increases when we extend our purview back to the Neoproterozoic, an interval from which many

56 discoidal fossils exist (MacGabhann, 2007, 2012, 2014). Recently, McGabhann (2007, 2012,

57 2014), Young \& Hagadorn (2010), Sappenfield, Tarhan, \& Droser (2016) provided a

58 comprehensive overview of disc-shaped and medusoid fossils, such that detailed consideration of

59 the phylogenetic affinities of a broad range of disc-shaped fossils and medusoids need not be

60 undertaken herein. Instead, the focus here is on some new material recovered from the Echo

61 Shale Member of the Carrara Formation (early Cambrian: Series 2, Stage 4, Dyeran) that seems

62 to resemble fossil specimens at times treated as either porpitids or eldonids. As part of a

63 discussion of the affinities of this new material, the fossil record of porpitids is also briefly

64 considered.

65

66 Geology and Paleoenvironment

67 The Carrara Formation is a regionally extensive, relatively shallow-water, mixed carbonate-

68 siliciclastic unit of lower to middle Cambrian (Dyeran to Delamaran; Bonnia-Olenellus Biozone

69 to Glossopleura Biozone) age in southern Nevada and southeastern California (Fig. 1A; Barnes 
70 \& Palmer, 1961; Barnes et al., 1962; Palmer \& Halley, 1979; Adams, 1995; Webster, 2011;

71 Harwood Theisen \& Sumner, 2016). It consists of mixed carbonate and siliciclastic sediments

72 and varies in thickness between 300-500m (Adams \& Grotzinger, 1996; Keller et al., 2012).

73 Previous investigations indicate deposition in peritidal to shallow-subtidal conditions (Palmer \&

74 Halley, 1979; Keller et al., 2012).

75

76 The Echo Shale Member was deposited in a lagoonal environment and is dominated by shales

77 and siliceous mudstones, interbedded with silt- and sandstone beds; it is thickest in the Striped

78 Hills area and thins out to the northwest (Palmer \& Halley, 1979; Adams 1995). It lies within the

79 Bolbonelellus euryparia Biozone (Webster, 2011), overlays the Thimble Limestone Member,

80 and in turn is overlain by the Gold Ace Limestone Member (Fig. 1B). The member is fossil poor

81 and only a few trilobite species have been reported in the literature (Palmer \& Halley, 1979).

82

83 The specimens were collected in the Nopah Range, California, U.S.A., 35 53'35.56" N $116^{\circ} 04^{\prime}$

$8439.27 " \mathrm{~W}$, at an elevation of about 820 meters, and derive from float closely associated with

85 greenish siliceous mudstones of the Echo Shale Member of the Carrara Formation. The rock

86 slab the specimens are on also contains specimens of an olenelloid trilobite (KUMIP 431473),

87 probably Bristolia Harrington, 1956, confirming the stratigraphic assignment.

\section{Materials and Methods}


92 In any instance involving putative fossils of simple morphology that contain few diagnostic

93 characters it is necessary to ascertain the biogenicity of the samples (Ruiz et al., 2004;

94 MacGabhann, 2007; Kirkland et al., 2016). To help verify that the specimens were not

95 abiological, pseudo- or dubiofossils sensu (Hofmann; 1971; Hofmann, Mountjoy, \& Teitz, 1991;

96 Gehling, Narbonne, \& Anderson, 2000; and MacGabhann, 2007), elemental mapping utilizing

97 energy dispersive X-ray spectroscopy (EDS) was conducted using an Oxford Instruments $80 \mathrm{~mm}^{2}$

98 x-Max silicon drift detector (SDD), mounted on an FEI Versa 3D Dual Beam. The use of this

99 approach applied to fossils in general, and Burgess Shale type fossils in particular, was pioneered

100 by Orr, Briggs, \& Kearns (1998). It has also been employed to study Ediacaran fossils by

101 Laflamme et al. (2011) and Cai et al. (2012), and notably MacGabhann (2012) has applied it to

102 specimens of $D$. peltatum from a different locality. Analyses conducted in the present study used

103 a horizontal field width of $2.39 \mathrm{~mm}$, a $\mathrm{kV}$ of 10 , a spot size of 4.5 , and a 1,000 micron opening

104 (no aperture). EDS maps were collected at a pixel resolution of 512x512 with a total of 18

105 passes. Analyses were conducted on two different parts of University of Kansas, Biodiversity

106 Institute, Division of Invertebrate Paleontology (KUMIP) specimen 389538 (the best preserved

107 specimen).

108

109 The specimens in Fig. 2 were photographed using a Canon EOS 5D Mark II digital SLR camera

110 equipped with Canon $50 \mathrm{~mm}$ macro lens. The specimens in Fig. 3 were photographed using an

111 Olympus UC50 camera attached to an Olympus SZX16 stereo microscope equipped with an

112 Olympus SDF PLAPO 0.5XPF lens. Pictures were taken with specimens submerged in alcohol.

113 The contrast, color, and brightness of images were adjusted using Adobe Photoshop. 
115 The biota of the Echo Shale Member consists of olenelloid trilobites, possible agnostoids, and

116 the herein illustrated disc-shaped fossils. The disc-shaped fossils are preserved as part and

117 counter part of brown-grey carbonaceous films, and specimens KUMIP 389538 and KUMIP

118389540 preserve some interior structure. The outer edge of KUMIP 389539 is vaguely preserved

119 and the missing interior structure suggests partial decomposition of the type described by

120 Kimmig \& Pratt (2016). This could be due to scavenging (an unidentified phosphatic fossil is

121 preserved next to it), pre-burial microbial decomposition, and/or diagenetic effects. The

122 specimens are flattened, and that appears to have generated minor concentric wrinkles at the

123 edge, best seen in KUMIP 389538. (MacGabhann [2012] provided a very useful and detailed

124 discussion of the taphonomy and preservation of Discophyllum specimens from the Ordovician

125 of Morocco.) The Bristolia trilobite on the slab preserves the cephalon, and possibly part of the

126 thorax, and appears to have been preserved completely articulated (Fig. 2A). The bulk of the

127 thorax and pygidium are missing though because the specimen sits at the edge of the slab.

128

129 Results

130

131 Results derived from both EDS analyses are congruent (Figs. 4, 5). The bulk mineralogy of the

132 specimens was determined to be equivalent to that of the surrounding rock: either SiAlO or

$133 \mathrm{SiFeAlO}$ depending on the part of the fossil/matrix analyzed. Spectral maps indicated the

134 following variations in percentage by weight for different detectable elements: $\mathrm{Si}, 23.1-24.0 \%$;

135 Al, 13.7-14.2\%; Fe, 7.0-16.8\%; K, 4.2-6.3\%; Ca, 1.1-2.0\%; Na, <.1-1.1\%; Mg, <.1-.8\%; Mn<.1-

$136.5 \% ; \mathrm{Ti},<.1-.4 \% ; \mathrm{P}<.1-.2 \%$; and $\mathrm{S}<.1-.1 \%$ (see included supplemental files). Given that Mn

137 was barely detectable $(.5 \%)$ or below detectable levels $(<.1 \%$ in sample illustrated $)$ in both the 
138 fossil and the surrounding matrix (see included supplemental files), the fossil cannot be the

139 typically inorganic mineral precipitate pyrolusite. Si, S, Al, K, Na, and Ti levels were found to

140 be identical in the fossils and the surrounding matrix (Figs. 4, 5). Fe levels were primarily

141 uniform throughout both the rock and fossil for the sample analyzed, although in one instance Fe

142 levels are slightly elevated, both on and off of the specimen (Figs. 4, 5). This, in conjunction

143 with the fact that the sample morphology is not in line with typical, abiologic mineral

144 precipitates, indicates that the fossils were not simply some form of inorganic mineral precipitate

145 such as hematite, pyrite, or marcasite. Mg levels are primarily uniform throughout, although

146 again there are a few elevated patches on and off the specimen (Figs. 4, 5). There are only three

147 elements that show any consistent elevation associated with the fossil (Figs. 4, 5). The first is C,

148 which seems to be elevated in moderately large, rounded patches, distributed seemingly at

149 random across the fossils, and also along the margin of the specimen (Figs. 4, 5). In a few cases

$150 \mathrm{C}$ is slightly elevated, though in much lower densities in terms of both patch size and

151 distribution, in the surrounding rock. The patchiness of the $\mathrm{C}$ may indicate partial weathering of

152 the fossil. Ca is also elevated in places, with a few moderately large, rounded patches, but these

153 are distributed only on parts of the fossils, and also along the margin of the fossil (Figs. 4, 5).

154 The Ca could perhaps represent recent diagenetic alteration associated with weathering or early

155 diagenetic cement. Finally, $\mathrm{P}$ is uniformly distributed in the fossil and the surrounding matrix at

156 low levels, except there appears to be some elevation along the margins of the specimen (Figs. 4,

157 5); the preservation of these specimens does not appear to represent the type of phosphatization 158 described by Xiao, Zhang, \& Knoll (1998). 
160 EDS analyses thus seem to indicate the fossils are at least partly preserved as a kerogenized

161 carbon film, which is consistent with a specific type of soft-bodied, Burgess Shale type

162 preservation that has been identified (Butterfield, 1990; Moore \& Lieberman, 2009). Not all

163 Burgess Shale type fossils show such a preservational style (Orr, Briggs, \& Kearns, 1998;

164 Gabbott et al., 2004). Often, these fossils are replicated as clay minerals, with parts of the fossils

165 elevated in characteristic elements present in clay minerals such as $\mathrm{K}, \mathrm{Al}$, and $\mathrm{Mg}$ (Orr, Briggs,

166 \& Kearns, 1998); at other times pyrite can play a significant role in replicating tissues (Gabbott

167 et al., 2004). The existence of some partial elevation for both $\mathrm{Mg}$ and Fe in the specimen

168 analyzed may also indicate a role for clay minerals and pyrite in the preservation process as well.

169 Moore \& Lieberman (2009) did previously identify instances in the Cambrian of Nevada,

170 U.S.A., from localities relatively stratigraphically and geographically close to the locality these

171 specimens come from, when soft-bodied fossils were preserved as carbon films; they also

172 identified instances from these nearby localities when fossils were preserved as clay minerals

173 and/or pyrite. Other taphonomic processes associated with enrichment in the elements $\mathrm{P}$ and $\mathrm{Ca}$

174 could perhaps be playing some role in the preservation of these porpitid fossils. Notably, the

175 EDS analyses of MacGabhann (2012) suggested that somewhat different taphonomic processes

176 were associated with the preservation of Discophyllum specimens from the Ordovician of

177 Morocco, especially involving no prominent role for $\mathrm{C}$, although this is perhaps not unexpected

178 given their different sedimentology and reconstructed paleoenvironments relative to what is

179 known from the Cambrian Carrara Formation.

180

181 Taxonomy: The specimens are tentatively placed with Discophyllum Hall, 1847, a monospecific 182 genus for D. peltatum Hall, 1847 (p. 277, pl. LXXV, fig. 3) (see also MacGabhann, 2012, figs. 
$1834.68,4.69$ ), originally described from the Upper Ordovician (Mohawkian) Trenton group, near

184 Troy, New York, U.S.A (see MacGabhann, 2012, figs. 3.28-3.30 for illustrations of the locality).

185 The specimens are referred to cf. Discophyllum sp. Hall, 1847, and greater justification for this

186 taxonomic assignment is provided below. More information on D. peltatum is also provided

187 below and in: Walcott (1898, p. 101, pl. XLVII, figs. 1, 2); Ruedemann (1916, p. 26, pl. XLVII,

188 figs. 1, 2; 1934, p. 31, pl. 12, figs. 1, 2); Chapman (1926, p. 14); Caster, (1942, p. 83); Zhu,

189 Zhao, \& Chen, (2002, p. 180) (where it is referred to as D. paltatum); Fryer \& Stanley (2004, p.

190 1117); and comprehensively in MacGabhann (2012, p. 122, figs. 4.68-4.113, figs. 5.15-5.53).

191

192 If Discophyllum is a porpitid, as has been previously suggested, it would be classified as: Phylum

193 Cnidaria Verrill, 1865; Class Hydrozoa Owen, 1843; Subclass Hydroidolina Collins, 2002;

194 Order Anthoathecata Cornelius, 1992; Suborder Capitata Kuhn, 1913; Superfamily Porpitoidea

195 Goldfuss, 1818; and Family Porpitidae Goldfuss, 1818. This follows the most up to date

196 treatments available: Daly et al. (2007) and WoRMS (2015). However, MacGabhann (2012,

197 2014) suggested an alternative placement for this taxon in an enigmatic group that was formerly

198 largely Cambrian in age, the eldonids, including the eponymous Eldonia Walcott, 1911. The

199 material presented here is not sufficiently well preserved to ascertain a higher-level taxonomic

200 assignment. For additional discussion about higher-level taxonomic assignments of fossil

201 porpitids see Fryer \& Stanley (2004) and also MacGabhann (2012); for discussion on the early

202 fossil record of Cnidaria see Van Iten et al. (2014).

203 Referred specimens: KUMIP 389538-389540. 
205 Remarks: A total of three closely associated specimens from a small slab were collected; they

206 are each preserved as both part and counterpart. All specimens are ovate in overall form, having

207 a slightly elongated antero-posterior axis. The presumed dorsal side preserves a prominent set of 208 rays or ridges that radiate from the central region. These could be akin to the radial flutes and

209 folds of the float of modern and fossil porpitids (see Yochelson, 1984 and Fryer \& Stanley, 2004

210 for discussion) but also might represent other structures seen in eldonids by MacGabhann (2012,

211 2014). In cases it appears that some of the rays or ridges may split (Fig. 3). It is not possible to

212 determine if this was caused by post-mortem decay or represents actual biology. If the latter, it

213 would be congruent with what MacGabhann (2012) identified as secondary or tertiary ridges in

214 eldonids. The details of the central region are sometimes obscured, but in KUMIP 389538 and

215389540 (Figs. 2, 3) there appears to be a small ovate structure from which the rays radiate. The

216 margins of the disc show a faintly scalloped pattern. Concentric corrugations are absent. There

217 is no evidence of a keel or sail as should be found in Velella Lamarck, 1801 (see Fryer \&

218 Stanley, 2004). Evidence of structures lateral of the radial ridges or fibers seems to be lacking,

219 so there does not appear to be evidence of tentacles extending beyond the margin of the float.

220 All specimens are preserved in low relief, and thus do not have cap-shaped relief, nor do they

221 show evidence of deformation consistent with compression of an originally cap-shaped relief.

222 There is no evidence of a coiled sac or dissepiments of the type identified by MacGabhann

223 (2012), but this could be due to relatively poor preservation. The type specimens of $D$. peltatum

224 Hall, 1847 were originally reposited in the Troy Lyceum (see Walcott, 1898) (the Troy Lyceum

225 became today's Rensselaer Polytechnic Institute) and are now at the Field Museum of Natural

226 History (see MacGabhann, 2012). We have provided two alternative taxonomic assignments,

227 and we concur with Conway Morris, Savoy, \& Harris (1991, p. 149-150) that "in the absence of 
228 diagnostic soft-parts, placement of certain discoidal fossils in" what are today known as the

229 capitates (formerly the chondrophorines), can be challenging.

230

231 Discussion

232

233 Most discoidal unbiomineralized fossils of Paleozoic age have been compared or referred to one

234 of three groups: cnidarian medusae (Young and Hagadorn, 2010), the capitate hydrozoans (Fryer

235 and Stanley, 2004) (previously referred to as chondrophorines), or the eldonids (MacGabhann,

236 2012). Comparisons are also made to discoidal specimens of Ediacaran age (e.g. Kirkland et al., 237 2016).

238

239 Comparison with discoidal taxa of Ediacaran age: The vast majority of described

240 unbiomineralized discoidal fossils have been found in sedimentary rocks of Ediacaran age. The

241 Carrara specimens bear little resemblance to any material known from the Ediacaran

242 (MacGabhann, 2007). The most apparent distinction is taphonomic, with Ediacaran discoidal

243 specimens generally preserved as positive hyporelief casts or negative epirelief molds on

244 bedding surfaces (MacGabhann, 2014), fundamentally different from the preservation of the

245 Carrara specimens as carbonaceous compressions. This does not preclude a comparison, as

246 species can, of course, have specimens preserved in more than one taphonomic style (e.g. Zhu et

247 al., 2008; MacGabhann, 2012). However, more importantly, there is little morphological data to

248 suggest a link between these specimens and any of Ediacaran age. 
250 Certain discoidal impressions of Ediacaran-aged taxa have at times been assigned to the

251 Hydrozoa in general and the Porpitidae in particular (for additional information on such

252 Ediacaran-aged specimens see Sprigg, 1947, Wade, 1972, Glaessner, 1979, Fedonkin, 1981,

253 Stanley \& Kanie, 1985, and Sun, 1986). There are few similarities between these specimens and

254 those described herein, except for the overall discoidal shape. For example, Eoporpita medusa

255 Wade, 1972 consists of a small concentrically ornamented disc surrounded by radial structures,

256 while Hiemalora Fedonkin, 1982 has a prominent and generally smooth central disc, with much

257 wider radial structures that show prominent relief (Narbonne, 1994). Cyclomedusa davidi

258 possesses radial striations, but these do not continue into the central circular zone (Sprigg, 1947,

259 1949). None of these resemble the material described herein, which lacks clear concentric

260 structures.

261

262 Comparison is rendered difficult, however, by the taxonomic irregularities and complexity

263 between and within Ediacaran discoidal genera and species (MacGabhann, 2007). Many

264 specimens assigned to Cyclomedusa Sprigg, 1947 consist solely of concentric rings and lack

265 radial features entirely. The same is true of species referred to Spriggia Southcott, 1958. It is

266 also true of Kullingia delicata (Fedonkin, 1981), which occurs in both Ediacaran rocks and in

267 Lower Cambrian strata in Newfoundland (Narbonne et al., 1991). Notably, Kullingia appears to

268 be a trace fossil (scratch circle) that was produced by an anchored, tubular organism (Jensen et

269 al., 2002; Sappenfield, Tarhan, \& Droser, 2016). Other Ediacaran discoidal forms are now

270 known to be pseudofossils (e.g. Menon et al., 2016). 
272 None of these Ediacaran specimens are still thought to represent hydrozoans (e.g. Zhang, Hua, \&

273 Reitner 2006, Cartwright et al., 2007, MacGabhann, 2007, and references therein). Young \&

274 Hagadorn (2010) reiterated this perspective when they noted that in many of these taxa the radial

275 structures cannot be interpreted as radial canals. Indeed, the Ediacaran discoidal fossils have

276 been recognized as benthic organisms, rather than pelagic forms, since Seilacher (1984).

In fact, most discoidal Ediacaran fossils are now thought to represent holdfasts of epibenthic stalked organisms, with the differences between specimens often due simply to taphonomic variation. For instance, Gehling, Narbonne, \& Anderson (2000) identified three major morphs of Aspidella Billings, 1872, which they suggested represent holdfast taphonomic variants (see also Tarhan et al. 2015, but see MacGabhann, 2007). The specimens described herein differ from the Aspidella 'type' morph by the lack of a prominent central slit, from the 'flat' morph by the lack

284 of concentric rings, and from the 'convex' morph by the lack of a prominent central boss

285 (Gehling, Narbonne, \& Anderson (2000). Indeed, there is no prima facie reason to suggest a

286 holdfast nature for these fossils, with no evidence for a benthic habit or stalk attachment

287 (Gehling, Narbonne, \& Anderson, 2000; Sappenfield, Tarhan, \& Droser, 2016). For similar

288 reasons, cf. Discophyllum sp. is also different from the Ediacaran-aged material that Hofmann

289 (1971) and Hofmann, Mountjoy, \& Teitz (1991) classified and illustrated as "dubiofossils" of 290 questionable biological affinities.

292 Comparison to cnidarian medusae: Cambrian cnidarian medusae have been described from 293 several localities, including multiple sites in the United States (Hagadorn, Dott, and Damrow, 294 2002; Cartwright et al., 2007; Hagadorn and Belt, 2008; Lacelle, Hagadorn, and Groulx, 2008; 
295 Young and Hagadorn, 2010; Hagadorn and Miller, 2011; Sappenfield, Tarhan, \& Droser, 2016).

296 These are generally large, preserved as molds and casts, with convex sediment rings, and have

297 quadripartite cracks. Clear criteria for the recognition of ancient medusae have been outlined by

298 Young and Hagadorn (2010). Other bona fide medusae preserve considerably more anatomy

299 than seen in the Carrara discs (e.g. Cartwright et al., 2007; Adler and Röper, 2012). As for the

300 comparison to Ediacaran discoidal taxa, the fossils described herein resemble bona fide medusae

301 only in terms of the overall discoidal shape, making such an affinity unlikely.

302

303 Comparisons with fossil capitates: cf. Discophyllum sp. also differs from what seem to be bona

304 fide fossil capitates. For instance, it differs from the capitate Palaelophacmaea valentinei

305 Waggoner \& Collins, 1995 from the Middle Cambrian Cadiz Formation of California, which has

306 more prominent relief in lateral profile and is more cap-shaped. In addition, $P$. valintinei has

307 well defined concentric circles, whereas these are lacking in cf. Discophyllum sp. It also differs

308 from Plectodiscus cortlandensis Caster, 1942 from the Upper Devonian of New York State, as

309 well as other species of Plectodiscus Rauff, 1939 from the Devonian Hunsrück Slate of Germany

310 (Bartels, Briggs, \& Bassel, 1998; Etter, 2002) and the Carboniferous of Malaysia (Stanley \&

311 Yancey, 1986). These have vellelid-like traits, including a sail. They also preserve few radial

312 structures, instead bearing prominent concentric circles that are interpreted as chitinous air

313 canals. Note, regarding the Hunsrück material, here we are referring to the completely preserved

314 specimens illustrated in Bartels, Briggs, \& Bassel (1998) and Etter (2002). As Bartels, Briggs, \&

315 Bassel (1998) usefully mentioned, it is not entirely clear if the isolated large disc-shaped

316 structures from this deposit discussed by Yochelson, Stürmer, \& Stanley (1983) actually

317 represent the same animal; instead these may represent a mollusk, a brachiopod, or salt 
318 pseudomorphs (see also Otto, 2000 and references therein). MacGabhann (2012) noted that

319 some specimens of Plectodiscus may represent scratch circles.

320

321 Oliver (1984) provided a detailed discussion of Conchopeltis alternata Walcott, 1876 from the

322 Ordovician Trenton Limestone of New York State. Glaessner (1971) and Stanley (1982) treated

323 this species as a chondrophorine (capitate in modern parlance), though Oliver (1984) hesitated to

324 assign it to that suborder. It has prominent radial structures projecting from a circular to ovate

325 interior space; overall, it also has a semi-ovate form. However, it does show some relief in

326 lateral view (perhaps attributable to its preservation in limestone), and some specimens possess

327 four-fold symmetry.

328 Finally, Caster (1942) considered Palaeoscia floweri Caster, 1942 from the Upper Ordovician of

329 the Cincinnati region to be a porpitid. Such an interpretation is certainly possible. However,

330 specimens are largely devoid of radiating lines except near the central, apical region, where they

331 diverge from a central pore-like structure. Instead, Caster's (1942) specimens are primarily

332 dominated by prominent concentric bands and thus differ significantly from cf. Discophyllum sp.

333 Again, some specimens of Palaeoscia are almost certainly scratch circles, as is Aysenspriggia

334 Bell, Angseesing, \& Townsend, 2001, from the Cretaceous of Chile.

335

336 Comparisons with miscellaneous fossil medusozoans: Yochelson \& Mason (1986) described a

337 specimen from the Mississippian of Kentucky that they cautiously treated as a chondrophorine

338 (capitate of current taxonomy), but its affinities instead seem to belong more likely with the

339 Scyphozoa, as it shows prominent circular coronal muscle bands. This specimen also lacks

340 prominent radial structures. Cherns (1994) described a medusoid from the Late Ordovician or 
341 Early Silurian but she suggested it was not a capitate, and we endorse her interpretation. These

342 differ from cf. Discophyllum sp. by the absence of prominent radial structures.

343

344 In terms of their relief, the Cararra specimens differ considerably from most species of Scenella

345 Billings, 1872 (e.g., Walcott, 1884; Yochelson \& Gil Cid, 1984; Babcock \& Robison, 1988; see

346 also discussion in Waggoner \& Collins, 1995). Scenella radians Babcock \& Robison, 1988 from

347 the Middle Cambrian of Utah does possess lines radiating from the center, KUMIP specimens

348 204347-204351, but the cap-shaped peak actually hooks slightly backward, which is unlike cf.

349 Discophyllum sp. Further, specimens of Scenella often display much more prominent concentric

350 elements (Yochelson \& Cid, 1984). As mentioned in Landing \& Narbonne (1992) and

351 Waggoner \& Collins (1995), several species of Scenella may in fact be mollusks, and thus the

352 affinities of these would be very distinct from the specimens discussed here.

353

354 Comparisons with eldonids: The most apt comparisons for the Carrara specimens seem to lie

355 with several post-Cambrian taxa that have previously been treated as porpitids, but seem instead

356 to have affinities with the eldonids (Conway Morris \& Robison, 1988; Dzik, 1991; Conway

357 Morris, 1993; Masiak \& Żylińska, 1994; Zhu, Zhao, \& Chen, 2002; and see MacGabhann, 2012,

358 for a detailed discussion of the eldonids, including a phylogeny). These are characterized by a

359 coiled sac near the center of a discoidal body, representing the digestive tract suspended within a

360 coelomic cavity.

361

362 The Carrara specimens are somewhat different from the Cambrian Rotadiscus Zhao \& Zhu,

363 1994, and Pararotadiscus Zhu, Zhao, \& Chen, 2002, both of which display clear concentric 
364 structures and have a dorsal surface which was stiffened. Our specimens also differ from the

365 Cambrian Velumbrella Stasińska 1960 (previously considered as a porpitid, but which may also

366 be an eldonid), due to the lack of a prominent annulus dividing inner and outer areas of the disc,

367 and differing style of radial structures; Velumbrella may also have had a stiffened disc surface, as

368 may the potential Ordovician eldonid Seputus MacGabhann and Murray, 2010.

370 Other eldonids are dominated by radial structures, including internal radial fibers and internal

371 lobes. The Cambrian Eldonia Walcott, 1911, and Stellostomites Sun \& Hou, 1987, both display

372 these structures, with post-Cambrian eldonids including Discophyllum Hall, 1847, and

373 Paropsonema Clarke, 1900, displaying radial ridges ornamenting the dorsal surface

374 (MacGabhann, 2012). The radially-arranged features of the Carrara specimens could represent

375 poorly preserved examples of internal lobes or dorsal ornamentation. However, specimens of

376 Eldonia and Stellostomites exhibiting internal lobes universally also preserve the coiled sac even

377 more prominently, with many additional specimens preserving the coiled sac but not the internal

378 lobes (MacGabhann, 2012). It is difficult to envisage how the radial structures in our specimens

379 could represent eldonid internal lobes without also preserving a coiled sac. An affinity with

380 Eldonia or Stellostomites thus seems unlikely.

381

382 However, it may be possible that the radial structures (Figs. 2, 3) could represent dorsal surface

383 ornamentation. Such ornamentation is seen in post-Cambrian eldonids, including Discophyllum

384 peltatum Hall, 1847, originally described from the Ordovician of New York; Parapsonema

385 cryptophya Clarke, 1900 from the Upper Devonian of New York (see also Ruedemann, 1916);

386 and Paropsonema mirabile Chapman, 1926, from the Silurian of Victoria, Australia. All of these 
387 display ridges radiating from a central point, with the coiled sac generally only visible where it is

388 preserved with relief from the surface. It is not inconceivable that the Carrara Formation

389 specimens could be preserving eldonid dorsal surface ornamentation without the relief necessary

390 to highlight the coiled sac.

391

392 Both species of Paropsonema show multiple cycles of radial ridges on the surface

393 (MacGabhann, 2012), unlike the specimens described herein. Discophyllum peltatum, however,

394 exhibits only a single cycle of radial ridges extending from the center to the margin. Although

395 the ridges of the Carrara Formation specimens appear to be more irregular that those of

396 Discophyllum peltatum, this could simply be a consequence of a different taphonomic style and

397 poor preservation in the Carrara material. The size and semi-ovate shape of the type material of

398 D. peltatum is also similar to the Carrara discs. A relationship therefore cannot be ruled out, and

399 the Carrara discs are certainly more similar to D. peltatum than any other previously described

400 discoidal fossils.

401 Due to the lack of clear diagnostic features of D. peltatum in the Carrara material, and the fact

402 that so far only three specimens have been collected from the Carrara Formation, it seems most

403 prudent to refer the Carrara material to cf. Discophyllum sp. The age differences between the

404 material from the Carrara Formation and the Ordovician of New York State may also suggest

405 they are unlikely to represent the same species. 
406 Acknowledgements

407

408 We thank Paulyn Cartwright (University of Kansas) for discussions about hydrozoan

409 morphology and taxonomy; Jisuo Jin, Brian Pratt, Graham Young, Kenneth De Baets, and an

410 anonymous reviewer for comments on earlier versions of the manuscript; Perry and Maria

411 Damiani for details on locality and site information; and Lisa Amati (NYSM), Bushra Husseini

412 (AMNH), Greg Dietl and Leslie Skibinski (PRI), and Daniel Levin (USNM) for information

413 about the whereabouts of specimens of Discophyllum peltatum.

416 References

417

418 Adams, R.D., 1995, Sequence-stratigraphy of Early-Middle Cambrian Grand Cycles in the

419 Carrara Formation, southwest basin and range, California and Nevada in Haq, B.U. eds.

420 Sequence Stratigraphy and Depositional Response to Eustatic, Tectonic and Climatic Forcing.

421 Amsterdam, Kluwer Academic, p. 277-328.

422 Adams, R.D., and Grotzinger, J.P., 1996, Lateral continuity of facies and parasequences in

423 Middle Cambrian platform carbonates, Carrara Formation, southeastern California, U.S.A:

424 Journal of Sedimentary Research, v. 66, p. 1079-1090.

425 Adler, L., and Röper, M., 2012, Description of a new potential fossil hydromedusa Palaequorea

426 rygoli and revision of the fossil medusa Hydrocraspedota mayri from the Plattenkalks of the

427 Franconian Alb, Southern Germany: Neues Jahrbuch für Geologie und Paläontologie-

428 Abhandlungen, v. 264, 249-262. 
429 Babcock, L.E., and Robison, R.A., 1988, Taxonomy and paleobiology of some Middle Cambrian

$430 \quad$ Scenella (Cnidaria) and hyolithids (Mollusca): University of Kansas Paleontological

$431 \quad$ Contributions, v. 121, p. 1-22.

432 Barnes, H., and Palmer, A.R., 1961, Revision of stratigraphic nomenclature of Cambrian rocks,

433 Nevada test site and vicinity, Nevada: U.S. Geological Survey Professional Paper 424-C, p.

434 C100-105.

435 Barnes, H., Christiansen, R.L., and Byers, F.M. Jr,1962, Cambrian Carrara Formation, Bonanza

436 King Formation, and Dunderberg Shale east of Yucca Flat, Nye County, Nevada: U.S.

437 Geological Survey Professional Paper 450-D, p. D27-31.

438 Bartels, C., Briggs, D.E.G., and Brassel, G., 1998, The Fossils of the Hunsrück Slate: New York,

439 Cambridge University Press, 309 p.

440 Bell, C.J., Angeesing, J., Townsend, M., 2001, A chondrophorine (medusoid hydrozoan) from

441 the Lower Cretaceous of Chile: Palaeontology, v. 44, p. 1011-1023.

442 Billings, E., 1872, On some fossils from the primordial rocks of Newfoundland: Canadian

$443 \quad$ Naturalist and Quarterly Journal of Science, new series, v. 6, p. 465-479.

444 Butterfield, N.J., 1990, Organic preservation of non-mineralizing organisms and the

445 taphonomy of the Burgess Shale: Paleobiology, v. 16, p. 272-286.

446 Cartwright, P., Halgedahl, S.L., Hendricks, J.R., Jarrard, R.D., Marques, A.C., Collins, A.G., and

447 Lieberman, B.S., 2007, Exceptionally preserved jellyfishes from the Middle Cambrian: PLoS

$448 \quad$ One, v. 2, e1121, p. 1-7.

449 Caster, K.E. Two siphonophores from the Paleozoic: Palaeontolographica Americana, v. 3(14),

$450 \quad$ p. $60-90$. 
451 Chapman, F., 1926, New or little known fossils in the National Museum. Part XXX. —A

452 Silurian jelly-fish: Proceedings of the Royal Society of Victoria, v. 39, p. 13-17.

453 Cherns, L., 1994, A medusoid from the Late Ordovician or Early Silurian of Jämtland, central 454 Sweden: Journal of Paleontology, v. 68, p. 716-721.

455 Clarke, J.M., 1900, Paropsonema cryptophya, a peculiar echinoderm from the Intumescens 456 zone (Portage beds) of western New York: New York State Museum, Bulletin, v. 39, p. $457 \quad 172-186$.

458 Clarke, J.M., and Ruedemann, R., 1903, Catalogue of type specimens of Paleozoic fossils in 459 New York State Museum: New York State Museum, Bulletin, v. 65, p. 1-847.

460 Collins, A.G., 2002, Phylogeny of Medusozoa and the evolution of cnidarian life cycles: 461 Journal of Evolutionary Biology, v. 15, p. 418-432.

462 Conway Morris, S., 1993, Ediacaran-like fossils in Cambrian Burgess Shale-type faunas of $463 \quad$ North America: Palaeontology, v. 36, p. 593-635.

464 Conway Morris, S., and Robison, R.A., 1988, More soft-bodied animals and algae from the 465 Middle Cambrian of Utah and British Columbia: University of Kansas Paleontological 466 Contributions, vol. 122, p. 23-48.

467 Conway Morris, S., Savoy, L.E., and Harris, A.G., 1991, An enigmatic organism from the 468 'Exshaw' Formation (Devonian-Carboniferous), Alberta, Canada: Lethaia, v. 24, p. 139$469 \quad 152$.

470 Cornelius, P.F.S., 1992, Medusa loss in leptolid hydrozoan (Cnidaria) hydroid rafting, and 471 abbreviated life-cycles among their remote-island fauna: an interim review: Scientia $472 \quad$ Marina, v. 56, p. 245-261. 
473 Daly, M., Brugler, M.R., Cartwright, P., Collins, A.G., Dawson, M.N., France, S.C., McFadden,

474 S.C., Opresko, N.M., Rodriguez, E., Romano, S., and Stake, J., 2007, The Phylum Cnidaria: A

475 review of phylogenetic patterns and diversity three hundred years after Linneaeus:

$476 \quad$ Zootaxa, v. 1668, p. 127-182.

477 Dzik, J., 1991, Is fossil evidence consistent with traditional views of early metazoan

478 phylogeny in Simonetta, A., and Conway Morris, S. eds. The Early Evolution of Metazoa

479 and the Significance of Problematic Taxa. New York, Cambridge University Press, p. 47-

$480 \quad 56$.

481 Etter, W., 2002, Hunsrück Slate: Widespread pyritization of a Devonian fauna in Bottjer,

482 D.J., Etter, W., Hagadorn, J.W., and Tang, C.M. eds. Exceptional Fossil Preservation: A

483 Unique View on the Evolution of Marine Life. New York, Columbia University Press, p.

$484 \quad 143-165$.

485 Fedonkin, M.A., 1981, Belomorskaya biota venda [The Vendian White Sea biota]: Trudy

486 Geological Institute, Academy Nauk SSSR, v. 342, p. 1-100.

487 Fedonkin, M.A., 1982, Novoye rodovoye nazvaniye dokembriyskikh kishechnopolostnykh

488 [A new generic name for some Precambrian coelenterates]: Paleontologicheskiy Zhurnal, $489 \quad$ v. $1982(2)$, p. 137.

490 Fryer, G., and Stanley, G.D., Jr., 2004, A Silurian porpitoid hydrozoan from Cumbria, England, 491 and a note on porpitoid relationships: Palaeontology, v. 47, p. 1109-1119.

492 Gabbott, S.E., Xiang-guang, H., Norry, M.J., and Siveter, D.J., 2004, Preservation of Early

493 Cambrian animals of the Chengjiang biota: Geology, v. 32, p. 901-904.

494 Gehling, J.G., Narbonne, G.M., and Anderson, M.M., 2000, The first named Ediacaran body

495 fossil, Aspidella terranovica: Palaeontology, v. 43, p. 427-456. 
496 Glaessner, M.F., 1971, The genus Conomedusites Glaessner and Wade and the diversification of

497 the Cnidaria: Paläontologische Zeitschrift, v. 45, p. 1-17.

498 Glaessner, M.F., 1979, Precambrian in Robison, R.A., and Teichert, C. eds. Treatise on

499 Invertebrate Paleontology Part A. Lawrence, Kansas, Geological Society of America and

$500 \quad$ University of Kansas Press, p. A79-A118.

501 Goldfuss, G.A., 1818, Ueber die classification der zoophyten: Isis, p. 1008-1013.

502 Hagadorn, J.W., and Belt, E.S., 2008, Stranded in upstate New York: Cambrian

503 scyphomedusae from the Potsdam Sandstone: Palaios, v. 23, p. 424-441.

504 Hagadorn, J.W., and Miller, R.F., 2011, Hypothesized Cambrian medusae from Saint John,

505 New Brunswick, reinterpreted as sedimentary structures: Atlantic Geology, v. 47, p. 6650680.

507 Hagadorn, J.W., Fedo, C.M., and Waggoner, B.M, 2000, Early Cambrian Ediacaran-type fossils 508 from California: Journal of Paleontology, v. 74, p. 731-740.

509 Hagadorn, J.W., Dott, Jr., R.H., and Damrow, D., 2002, Stranded on a Late Cambrian shoreline:

510 medusae from central Wisconsin: Geology, v. 30, p. 147-150.

511 Hall, J., 1847. Paleontology of New York, vol. 1: Natural History of New York, part 6, Albany, $512 \quad$ New York, 1-338.

513 Harrington, H.J., 1956, Olenellidae with advanced cephalic spines: Journal of Paleontology, v. 51430, p. $56-61$.

515 Harwood Theisen, C., and Sumner, D.Y., 2016, Thrombolite fabrics and origins: Influences of 516 diverse microbial and metazoan processes on Cambrian thrombolite variability in the Great 517 Basin, California and Nevada: Sedimentology, v. 63, p. 2217-2252. 
518 Hofmann, H.J., 1971, Precambrian fossil, pseudofossils, and problematica in Canada: Geological

519 Survey of Canada, Bulletin 189, p. 1-146.

520 Hofmann, H.J., Mountjoy, E.W., and Teitz, M.W., 1991, Ediacaran fossils and dubiofossils,

521 Miette Group of Mount Fitzwilliam area, British Columbia: Canadian Journal of Earth

$522 \quad$ Sciences, v. 28, p. 1541-1552.

523 Jensen, S., Gehling, J.G., Droser, M.L., and Grant, S.W.F., 2002, A scratch circle origin for the 524 medusoid fossil Kullingia: Lethaia, v. 35, p. 291-299.

525 Keller, M., Lehnert, O., and Cooper, J.D., 2012, Sauk megasequence supersequences, southern 526 Great Basin: Second-order accommodation events on the southwestern Cordilleran margin 527 platform: American Association of Petroleum Geologists Memoir, v. 98, p. 873-896.

528 Kimmig, J., and Pratt, B.R., 2016, Taphonomy of the middle Cambrian (Drumian) Ravens Throat 529 River Lagerst€atte, Rockslide Formation, Mackenzie Mountains, Northwest Territories, 530 Canada: Lethaia, v. 49, p. 150-169.

531 Kirkland, C.L., MacGabhann, B.A., Kirkland, B.L., and Daly, J.S., 2016, Cryptic disc structures 532 resembling Ediacaran discoidal fossils from the Lower Silurian Hellefjord Schist, Arctic 533 Norway: PLoS One, v. 11, e0164071, p. 1-21.

534 Kuhn, A., 1913, Entwicklungsgeschichte und verwandschaftsbeziehungen der hydrozoan. I. 535 Teil: Die Hydroiden: Ergebnisse der Fortschritte Zoologische, v. 4, p. 1-284.

536 Lacelle, M.A., Hagadorn, J.W., and Groulx, P., 2008, The widespread distribution of Cambrian 537 medusae: Scyphomedusae strandings in the Potsdam Group of southwestern Quebec: 538 Geological Society of America Abstracts with Programs, v. 40, p. 369.

539 Lamarck, J.-B., 1801, Système des Animaux sans Vertèbres: Paris, 338 p. 
540 Landing, E., and Narbonne, G.M., 1992, Scenella and "A chondrophorine (medusoid

541 hydrozoan) from the basal Cambrian (Placentian) of Newfoundland": Journal of

$542 \quad$ Paleontology, v. 66, p. 338-338.

543 Liu, A.G., Matthews, J.J., Menon, L.R., McIlroy, D., and Brasier, M.D., 2014, Haotia

544 quadriformis $\mathrm{n}$. gen., n. sp., interpreted as a muscular cnidarian impression from the Late

545 Ediacaran period (approx. 560Ma): Proceedings of the Royal Society, Series B, Biological

$546 \quad$ Sciences, v. 281, 20141202.

547 MacGabhann, B.A., 2007, Discoidal fossils of the Ediacaran biota: a review of current

548 understanding: Geological Society of London, Special Publications, v. 286, p. 297-313.

549 MacGabhann, B.A., 2012, A solution to Darwin's dilemma: Differential taphonomy of Ediacaran 550 and Palaeozoic non-mineralised discoidal fossils: PhD Thesis, National University of Ireland,

$551 \quad$ Galway, p. 1-338.

552 https://aran.library.nuigalway.ie/bitstream/handle/10379/3406/2012MacGabhannPhDvol1.pdf

$553 \quad$ ?sequence $=9$

554 MacGabhann, B.A., 2014, There is no such thing as the 'Ediacara Biota': Geoscience Frontiers, 555 v. 5, p. $53-62$.

556 MacGabhann, B.A., and Murray, J., 2010, Non-mineralised discoidal fossils from the Ordovician 557 Bardahessiagh Formation, Co. Tyrone, Ireland: Irish Journal of Earth Sciences, v. 28, p. 1$558 \quad 12$.

559 Masiak, M., and Zylinska, A., 1994, Burgess Shale-type fossils in Cambrian sandstones of the 560 Holy Cross Mountains: Acta Palaeontologica Polonica, v. 39, p. 329-340. 
561 Menon, L.R., McIlroy, D., Liu, A.G., Brasier, M.D., 2016. The dynamic influence of microbial

562 mats on sediments: fluid escape and pseudofossil formation in the Ediacaran Longmyndian

563 Supergroup, UK: Journal of the Geological Society, v. 173, p. 177-185.

564 Moore, R.A., and Lieberman, B.S., 2009, Preservation of early and Middle Cambrian soft-bodied

565 fossils from the Pioche Shale, Nevada, USA: Palaeogeography, Palaeoecology,

566 Palaeoclimatology, v. 277, p. 57-62.

567 Narbonne, G.M., 1994, New Ediacaran fossils from the Mackenzie Mountains, northwestern

568 Canada: Journal of Paleontology, v. 68, p. 411-416.

569 Narbonne, G.M., Myrow, P., Landing, E., and Anderson, M.M., 1991, A chondrophorine

570 (medusoid hydrozoan) from the basal Cambrian (Placentian) of Newfoundland: Journal

571 of Paleontology, v. 65, p. 186-191.

572 Oliver, W.A., Jr., 1984, Conchopeltis, its affinities and significance: Palaeontographica

$573 \quad$ Americana, v. 54, p. 141-147.

574 Orr, P.J., Briggs, D.E.G., and Kearns, S.L., 1998, Cambrian Burgess Shale animals replicated in 575 clay minerals: Science, v. 281, p. 1173-1175.

576 Ossian, C.R., 1973, New Pennsylvanian scyphomedusan from western Iowa: Journal of 577 Paleontology, v. 77, p. 990-995.

578 Otto, M., 2000, Supposed soft tissue preservation in the Hunsrückshiefer (Lower Devonian, 579 Rheinisches Schiefergebirge): the example of brachiopods: Paläontologische Zeitschrift, $580 \quad$ v. 74, p. $79-89$.

581 Owen, R. 1843, Lectures on the Comparative Anatomy and Physiology of the Invertebrate 582 Animals, Delivered at the Royal College of Surgeons: London, Longman, Brown, Green, 583 and Longmans, $424 \mathrm{p}$. 
584 Palmer, A.R. \& Halley, R.B., 1979. Physical stratigraphy and trilobite biostratigraphy of the

585 Carrara Formation (Lower and Middle Cambrian) in the southern Great Basin: $U . S$.

586 Geological Survey Professional Paper, v. 1047, p. 1-131.

587 Rauff, H., 1939, Palaeonectris discoidea Rauff, eine siphonophore medusa aus dem

588 rheinischen Unterdevon nebst bemerkungen zur umstrittenen Brooksella rhenana

589 Kinkelin: Paläontologische Zeitschrift, v. 21, p. 194-213.

590 Ruedemann, R., 1916, Account of some new or little-known species of fossils: New York

$591 \quad$ State Museum, Bulletin, v. 189, p. 7-97.

592 Ruedemann, R., 1934, Paleozoic plankton of North America: Geological Society of America

593 Memoir, v. 2, p. 1-141.

594 Ruiz, J.M.G., Carnerup, A., Christy, A.G., Wilhelm, N.J., and Hyde, S.T., 2004, Morphology: An

595 ambiguous indicator of biogenicity: Astrobiology, v. 2, p. 353-369.

596 Sappenfield, A.R., Tarhan, L.G., and Droser, M.L., 2016, Earth’s oldest jellyfish

597 strandings: a unique taphonomic window or just another day at the beach?

598 Geological Magazine, p. 1-16,

599 DOI: https://doi.org/10.1017/S0016756816000443.

600 Southcott, R.V., 1958, South Australian jellyfish: The South Australian Naturalist, v. 32, p.

$60153-61$.

602 Sprigg, R.C., 1947, Early Cambrian (?) jellyfishes from the Flinders Ranges, South Australia:

603 Transactions of the Royal Society of South Australia, v. 71, p. 212-224.

604 Stanley, G.D., 1982, Paleozoic chondrophores (medusoid hydrozoans) and their

605 implications for problematic mollusk-like fossils: Third North American Paleontological

606 Convention, Proceedings, v. 2, p. 501-504. 
607 Stanley, G.D., and Kanie, Y., 1985, The first Mesozoic chondrophorine (medusoid

608 hydrozoan) from the Lower Cretaceous of Japan: Palaeontology, v. 28, p. 101-109.

609 Stasinska, A., 1960, Velumbrella czarnockii n. gen. n. sp. Méduse du Cambrien inférieur des

610 Monts de Sainte-Croix: Acta Palaeontologica Polonica, v. 5, p. 337-346.

611 Sun, W.G., 1986, Precambrian medusoids: the Cyclomedusa-plexus and Cyclomedusa-like

612 pseudofossils: Precambrian Research, v. 31, p. 325-360.

613 Sun, W.G., and Hou, X., 1987, Early Cambrian medusae from Chengjiang, Yunnan, China:

614 Acta Palaeontologica Sinica, v. 26, p. 257-271.

615 Tarhan, L.G., Droser, M.L., Gehling, J.G., and Dzaugis, M.P., 2015, Taphonomy and

616 morphology of the Ediacara form genus Aspidella: Precambrian Research, v. 257, p.

$617 \quad 124-136$.

618 Van Iten, H., Marques, A., de Moraes Leme, J., Forancelli Pacheco, M.L.A., and Guimares

619 Simões, M., 2014, Origin and early diversification of the Phylum Cnidaria Verrill: Major

620 developments in the analysis of the taxon's Proterozoic-Cambrian history:

621 Palaeontology, v. 57, p. 677-690.

622 Verrill, A.E., 1865, Classification of polyps: Communications of the Essex Institute, v. 4, p. $623 \quad 145-152$.

624 Wade, M., 1972, Hydrozoa and Scyphozoa and other medusoids from the Precambrian 625 Ediacara fauna, South Australia: Palaeontology, v. 15, p. 197-225.

626 Waggonner, B.J., and Collins, A.G., 1995, A new chondrophorine (Cnidaria, Hydrozoa) from 627 the Cadiz Formation (Middle Cambrian) of California: Paläontologische Zeitschrift, v. 69, 628 p. $7-17$. 
629 Walcott, C.D., 1876, Descriptions of new species of fossils from the Trenton Limestone: New $630 \quad$ York State Museum of Natural History, 28 ${ }^{\text {th }}$ Annual Report, p. 93-97.

631 Walcott, C.D., 1884, Paleontology of the Eureka district: United States Geological Survey, 632 Monographs, v. 8, 298 p.

633 Walcott, C.D., 1898, Fossil medusa: United States Geological Survey, Monographs, v. 30, 201 634 p.

635 Walcott, C.D., 1911, Middle Cambrian Holothurians and medusa: Smithsonian Miscellaneous 636 Collections, v. 57, p. 41-68.

637 Webster, M. 2011. Trilobite biostratigraphy and sequence stratigraphy of the upper Dyeran 638 (traditional Laurentian 'Lower Cambrian') in the southern Great Basin, U.S.A: Museum of 639 Northern Arizona Bulletin, v. 67, p. 121-154.

640 WoRMS, 2015, Porpita porpita (Linnaeus, 1758), in Schuchert, P., World Hydrozoa 641 database. Accessed through World Register of Marine Species at 642 http://www.marinespecies.org/aphia.php?p=taxdetails\&id=117831 on 2016-03-06.

643 Xiao, S., Zhang, Y., and Knoll, A.H., 1998, Three-dimensional preservation of algae and 644 animal embryos in a Neoproterozoic phosphorite: Nature, v. 391, p. 553-558.

645 Yochelson, E.L., 1984, North American Middle Ordovician Scenella and Macroscenella as 646 possible chondrophorine coelenterates: Palaeontolographica Americana, v. 54, p. 148$647 \quad 153$.

648 Yochelson, E.L., and Gil Cid, D., 1984, Reevaluation of the systematic position of Scenella: 649 Lethaia, v. 17, p. 331-340. 
650 Yochelson, E.L., and Mason, C.E., 1986, A chondrophorine coelenterate from the Borden

651 Formation (Lower Mississippian) of Kentucky: Journal of Paleontology, v. 60, p. 10256521028.

653 Yochelson, E.L., Stürmer, W., and Stanley, G.D., 1983, Plectodiscus discoideus (Rauff): a 654 redescription of a chondrophorine from the Early Devonian Hunsrück Slate, West 655 Germany: Paläontologische Zeitschrift, v. 57, p. 39-68.

656 Young, G.A., and Hagadorn, J.W., 2010, The fossil record of cnidarian medusae: Palaeoworld, 657 v. 19, p. $212-221$.

658 Zhang, X., Hua, H., and Reitner, J., 2006, A new type of Precambrian megascopic fossils: the 659 Jinxian biota from northeastern China: Facies, v. 52, p. 169-181.

660 Zhao, Y.-L., and Zhu, M.-Y., 1994, Discoidal fossils of Kaili fauna from Taijiang, Guizhou: Acta 661 Palaeontologica Sinica, v. 33, p. 272-280.

662 Zhu, M.-Y., Zhao, Y.-L., and Chen, J.-Y., 2002, Revision of the Cambrian discoidal animals 663 Stellostomites eumorphus and Pararotadiscus guizhouensis from South China: Geobios, v. $664 \quad 35$, p. 165-185.

665 Figure captions

666

667 Figure 1: Locality and stratigraphy.

668 A) Map indicating where the specimens were derived from in the Nopah Range, Nevada, 669 U.S.A, with locality indicated by the star which represents $35^{\circ} 53^{\prime} 35.56^{\prime \prime} \mathrm{N} 116^{\circ} 04^{\prime} 39.27^{\prime \prime}$

670 W . B) A generalized stratigraphic chart for the Carrara Formation, with the star indicating the 671 member the specimens were collected from.

672 
673 Figure 2: The slab containing the fossil specimens.

674 A) Part and B) counterpart, where 1 = KUMIP 389538, 2 = KUMIP 389539, 3 = KUMIP

675 389540. Scale bar is $10 \mathrm{~mm}$.

676

677 Figure 3: cf. Discophyllum sp. Hall, 1847 from the Echo Shale Member of the Carrara

678 Formation.

679 A-D) Dorsal view of the part of KUMIP 389538. In A) scale bar is $1 \mathrm{~mm}$, the boxes surrounded

680 in black represent locations of C and D, and the boxes surrounded in blue were the regions

681 subjected to EDS analysis with the results from these shown in Figures 4 and 5, respectively. B)

682 Line drawing illustrating the preserved structures. C, D) Close-ups of different portions of the 683 specimen; scale bars are $500 \mu \mathrm{m}$. E) Dorsal view of the part of KUMIP 389540; scale bar is $6841 \mathrm{~mm}$. F) Dorsal view of the part of KUMIP 389539; scale bar is $1 \mathrm{~mm}$.

685

686

Figure 4: Element maps of KUMIP 389538 and surrounding rock matrix.

687 The region demarcated by the blue box labeled "Fig. 4" in Figure 3a was analyzed. Scale bars 688 are $1 \mathrm{~mm}$. Element map images were generated using Oxford Instruments AZtecEnergy EDS 689 software. These images were migrated into Adobe Photoshop 2014.2.1 CC to create a single 690 figure. No image manipulations were performed.

691

692 Figure 5: Element maps of a different portion of KUMIP 389538 and surrounding rock 693 matrix.

694 The region demarcated by the blue box labeled "Fig. 5" in Figure 3a was analyzed. Scale bars 695 are $1 \mathrm{~mm}$. Element map images were generated using Oxford Instruments AZtecEnergy EDS 
696 software. These images were migrated into Adobe Photoshop 2014.2.1 CC to create a single 697 figure. No image manipulations were performed.

698

699

700

701 
Figure 1

Locality and stratigraphy.

(A) Map indicating where the specimens were derived from in the Nopah Range, Nevada, U.S.A, with locality indicated by the star which represents $35^{\circ} 53^{\prime} 35.56^{\prime \prime} \mathrm{N} 116^{\circ} 04^{\prime} 39.27^{\prime \prime} \mathrm{W}$; (B) A generalized stratigraphic chart for the Carrara Formation, with the star indicating the member the specimens were collected from.

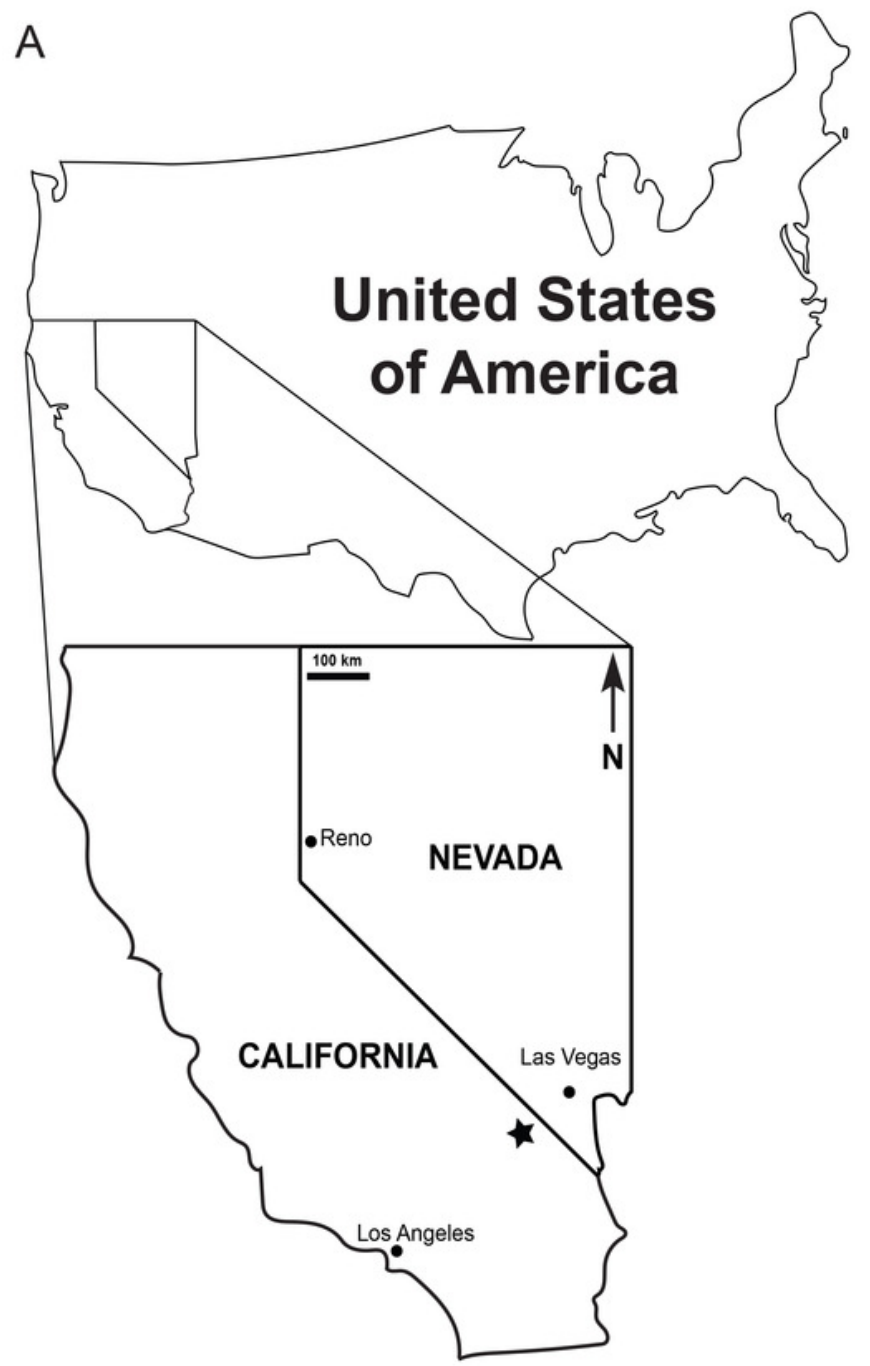

B

\begin{tabular}{|c|c|c|c|}
\hline \multirow{9}{*}{ 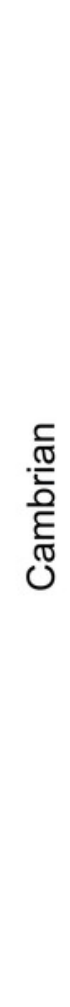 } & \multirow{5}{*}{ 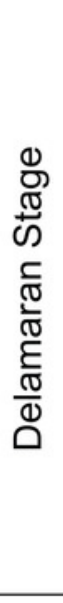 } & \multirow{9}{*}{ 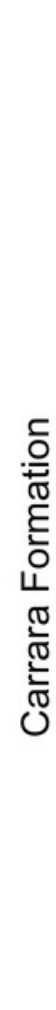 } & Desert Range Limestone Member \\
\hline & & & Jangle Limestone Member \\
\hline & & & Pahrump Hills Shale Member \\
\hline & & & Red Pass Limestone Member \\
\hline & & & Pyramid Shale Member \\
\hline & \multirow{4}{*}{ 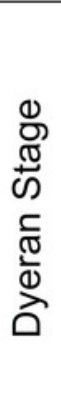 } & & Gold Ace Limestone Member \\
\hline & & & Echo Shale Member $\boldsymbol{x}$ \\
\hline & & & Thimble Limestone Member \\
\hline & & & Eagle Mountain Shale Member \\
\hline
\end{tabular}


Figure 2

The slab containing the fossil specimens.

(A) Part and (B) counterpart, where $1=$ KUMIP 389538, $2=$ KUMIP 389539, $3=$ KUMIP 389540. Scale bar is $10 \mathrm{~mm}$.
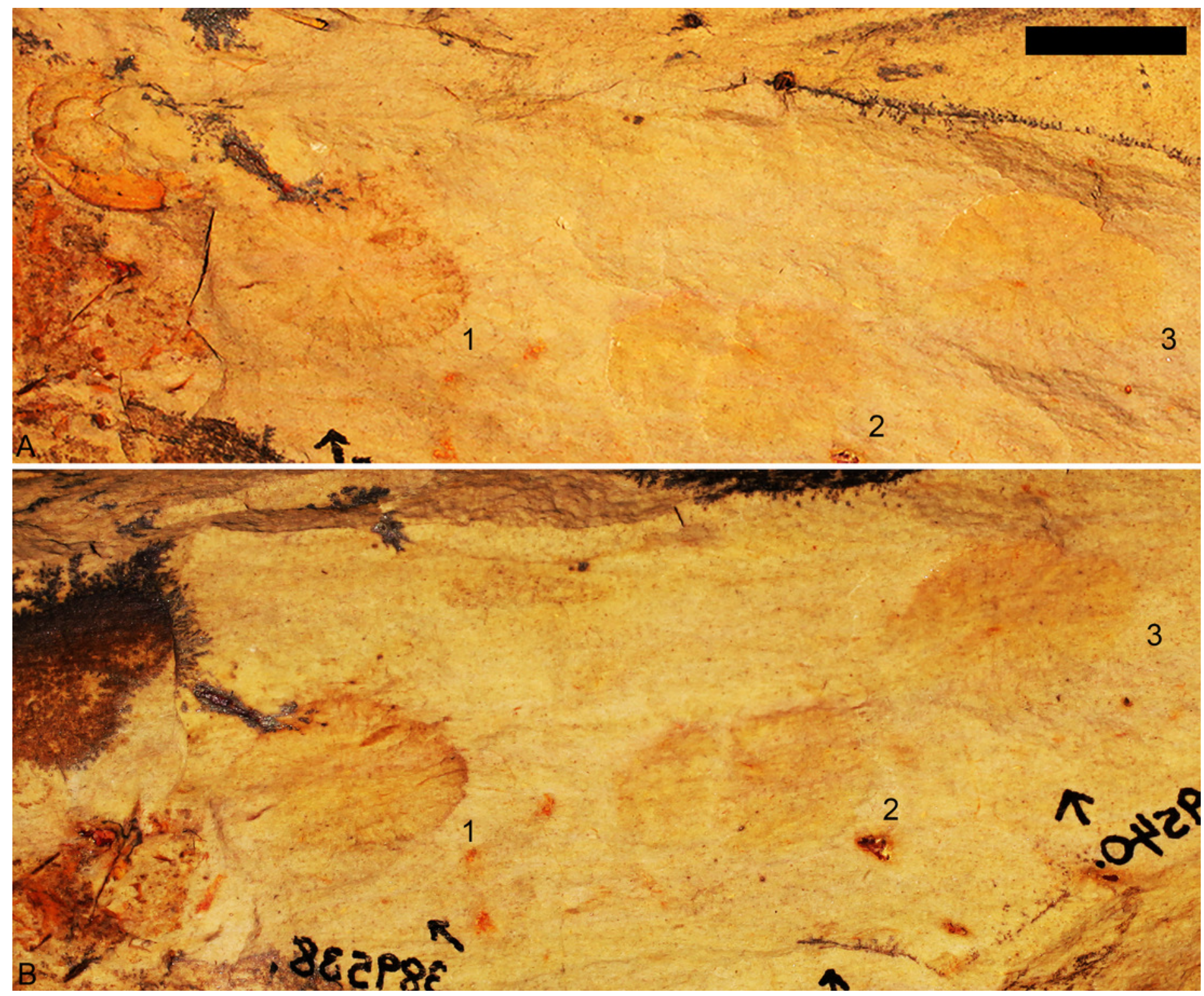


\section{Figure 3}

Discophyllum sp. Hall, 1847 from the Echo Shale Member of the Carrara Formation.

(A-D) Dorsal view of the part of KUMIP 389538. In (A) scale bar is $1 \mathrm{~mm}$, the boxes surrounded in black represent locations of $C$ and $D$, and the boxes surrounded in blue were the regions subjected to EDS analysis with the results from these shown in Figures 4 and 5, respectively; (B) Line drawing illustrating the preserved structures; (C, D) Close-ups of different portions of

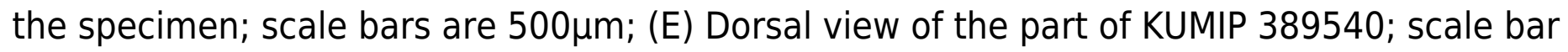
is $1 \mathrm{~mm}$; (F) Dorsal view of the part of KUMIP 389539; scale bar is $1 \mathrm{~mm}$. 

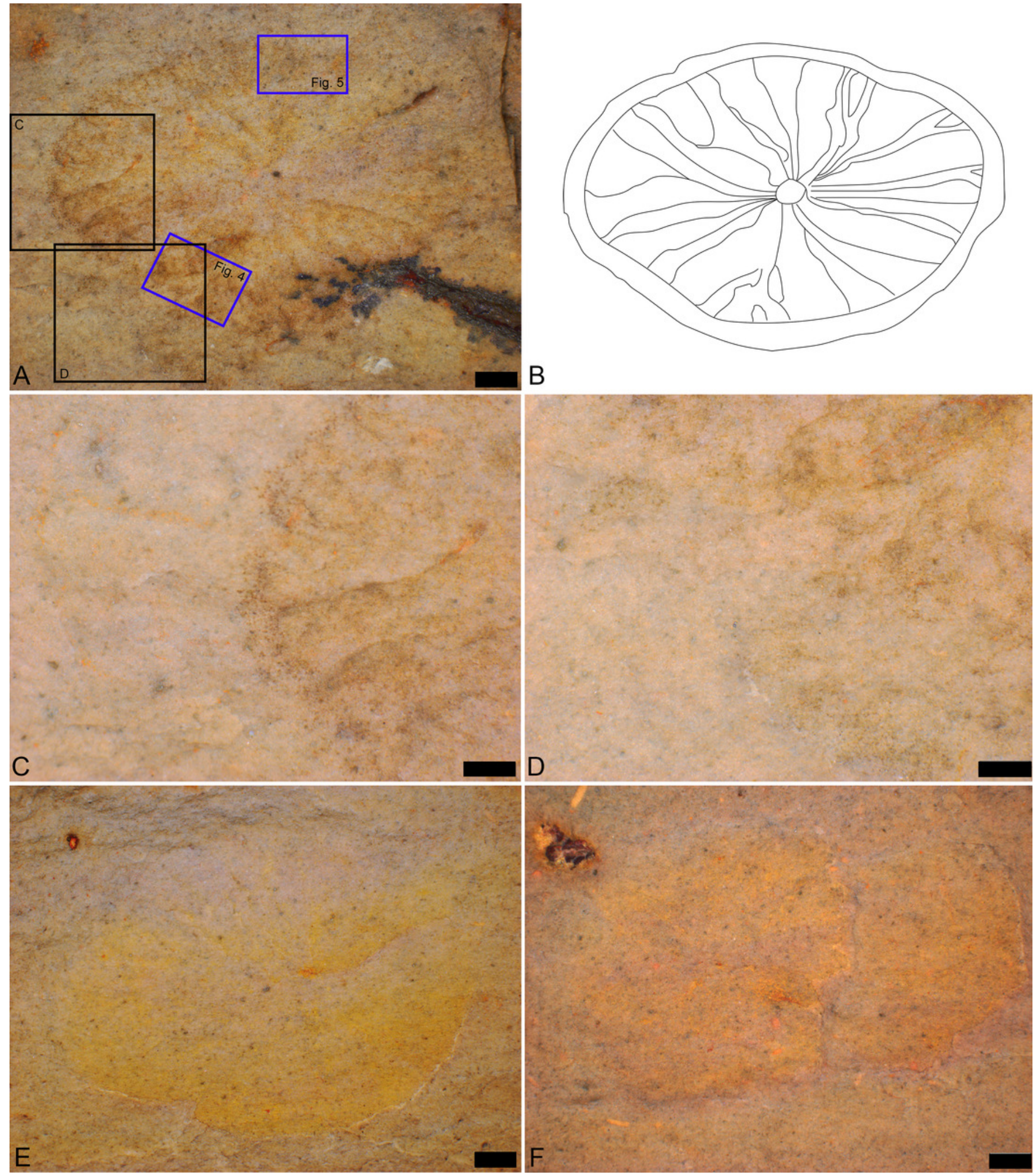


\section{Figure 4}

Element maps of KUMIP 389538 and surrounding rock matrix.

The region demarcated by the blue box labeled "Fig. 4" in Figure 3a was analyzed. Scale bars are $1 \mathrm{~mm}$. Element map images were generated using Oxford Instruments AZtecEnergy EDS software. These images were migrated into Adobe Photoshop 2014.2.1 CC to create a single figure. No image manipulations were performed.

*Note: Auto Gamma Correction was used for the image. This only affects the reviewing manuscript. See original source image if needed for review.

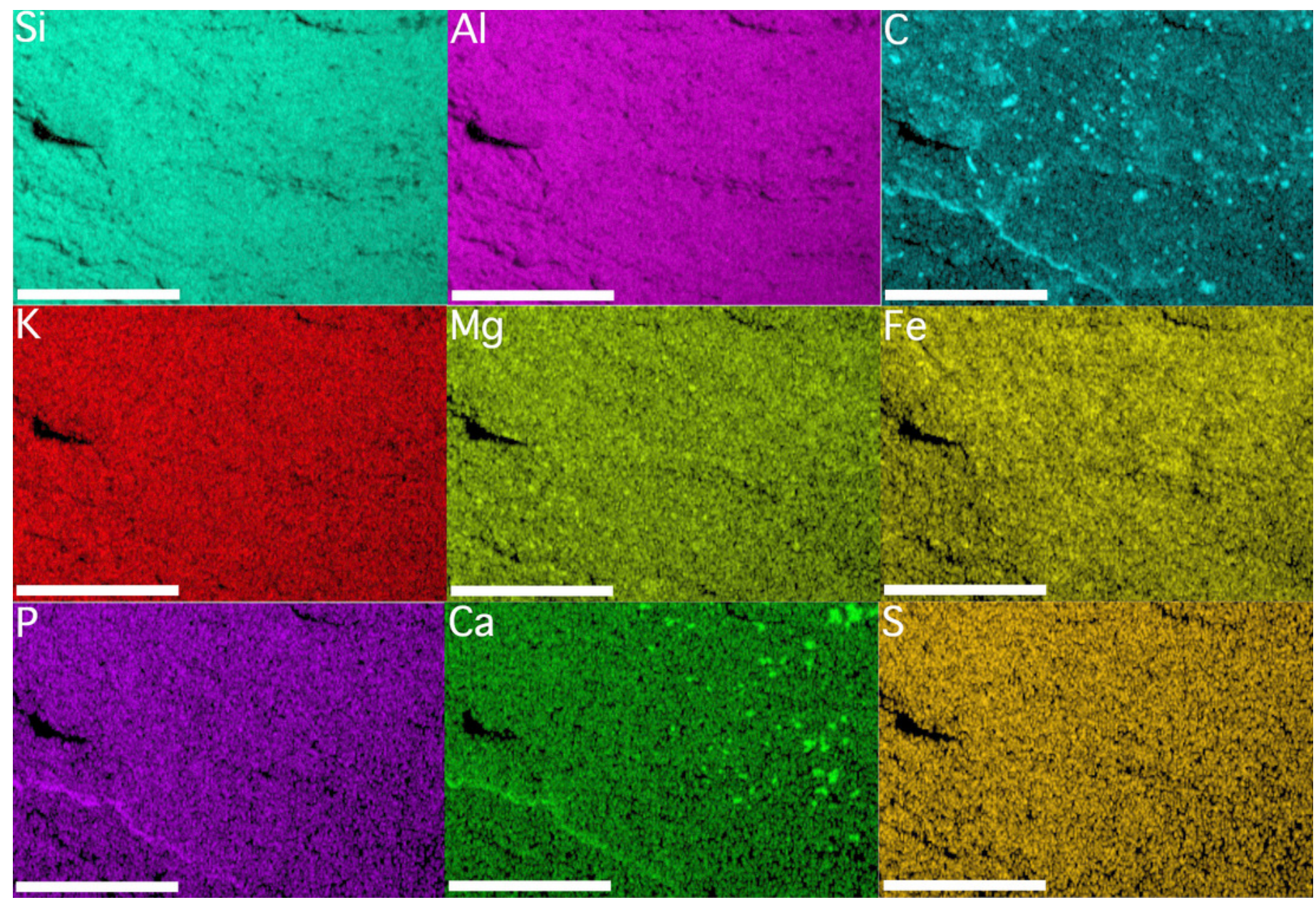




\section{Figure 5}

Element maps of a different portion of KUMIP 389538 and surrounding rock matrix.

The region demarcated by the blue box labeled "Fig. 5" in Figure 3a was analyzed. Scale bars are $1 \mathrm{~mm}$. Element map images were generated using Oxford Instruments AZtecEnergy EDS software. These images were migrated into Adobe Photoshop 2014.2.1 CC to create a single figure. No image manipulations were performed.

*Note: Auto Gamma Correction was used for the image. This only affects the reviewing manuscript. See original source image if needed for review.

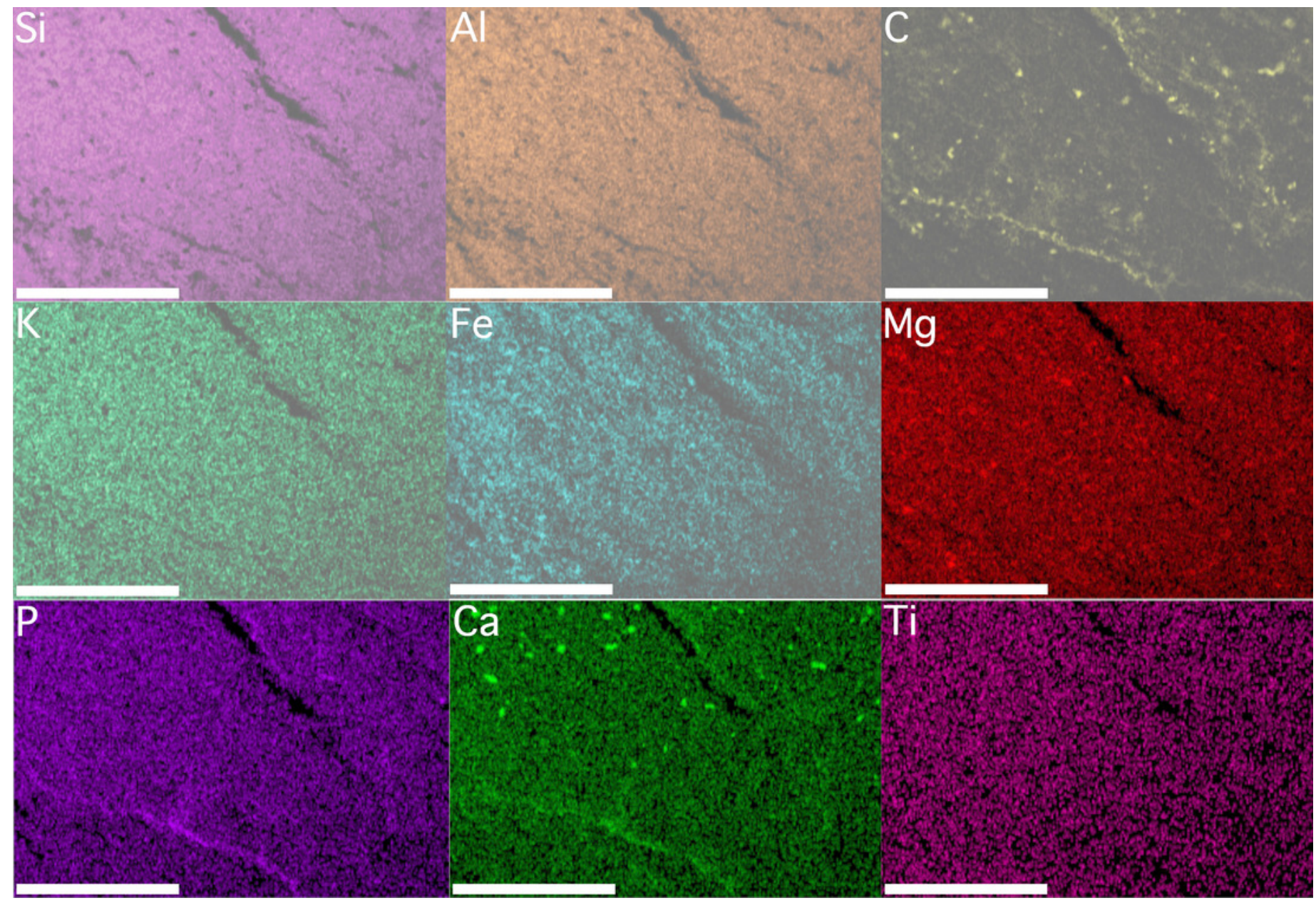

